\title{
Simultaneous Interphase Optimizations on Large-area Anode and Cathode of High-energy-density Lithium-ion Pouch Cells by a Multiple Additives Strategy
}

Xu-Feng Zang ${ }^{a}, *$, Zhendong $\mathrm{Li}^{b}$, Yishan Fang ${ }^{c}$, Yanping Hong ${ }^{d}$, Shengchen Yang ${ }^{e}$, Zhe Peng ${ }^{b, *}$, Shanshan $\operatorname{Sun} f, *$

${ }^{a}$ College of Science, Huzhou University, Zhejiang, Huzhou 313000, China

${ }^{b}$ Ningbo Institute of Materials Technology and Engineering, Chinese Academy of Sciences, Ningbo 315201, China

${ }^{c}$ State Key Laboratory of Biobased Material and Green Papermaking, School of Food Science and Engineering, Qilu University of Technology, Shandong Academy of Sciences, Jinan 250353, China

${ }^{d}$ Jiangxi Key Laboratory of Natural Product and Functional Food, College of Food Science and Engneering, Jiangxi Agricultural University, Nanchang 330045, China

${ }^{e}$ School of engineering, Huzhou University, Zhejiang, Huzhou 313000, China

${ }^{f}$ Ningbo Veken New Energy Co., Ltd. (China), Zhejiang, Ningbo 315800, China

*Corresponding author. E-mail address: zangxufeng@163.com (X. Zang), pengzhe@nimte.ac.cn (Z. Peng),xyz.5123@mail.163.com (S. Sun). 
Table S1. Proportion values of CC charging capacity on the total charging capacity $(\mathrm{CC}+\mathrm{CV})$ at various charge rates under $25^{\circ} \mathrm{C}$.

\begin{tabular}{cccc}
\hline \multirow{2}{*}{ Electrolyte } & \multicolumn{3}{c}{ Charge capacity proportion of CC in $(\mathrm{CC}+\mathrm{CV})$} \\
& $1 \mathrm{C}$ & $1.5 \mathrm{C}$ & $2 \mathrm{C}$ \\
\hline Base & 85.50 & 80.30 & 76.86 \\
Base+LFP & 85.51 & 80.32 & 76.77 \\
Base+DTD & 85.29 & 81.70 & 78.27 \\
Base+LiFSI & 85.37 & 81.82 & 78.44 \\
Mix & 85.47 & 81.93 & 78.50 \\
\hline
\end{tabular}

Table S2. Capacity retentions of the discharge capacity at high rates compared to that at $0.2 \mathrm{C}$ under $25^{\circ} \mathrm{C}$.

\begin{tabular}{clcc}
\hline \multirow{2}{*}{ Electrolyte } & \multicolumn{3}{c}{ Discharge capacity retention (\%) } \\
& 1 C & $1.5 \mathrm{C}$ & $2 \mathrm{C}$ \\
\hline Base & 92.97 & 89.04 & 79.01 \\
Base+LFP & 92.71 & 89.38 & 81.49 \\
Base+DTD & 93.18 & 90.65 & 82.39 \\
Base+LiFSI & 93.31 & 91.00 & 84.10 \\
Mix & 93.42 & 91.36 & 87.39 \\
\hline
\end{tabular}


Table S3. Discharge capacities and discharges time of the cells with different electrolytes under $-10{ }^{\circ} \mathrm{C}$ and $25^{\circ} \mathrm{C}$ at $0.2 \mathrm{C}$, and the discharge capacity retentions. It should be mentioned that the capacity displayed herein corresponds to the total capacity of each cell (not the specific capacity), and depends on the thickness of the electrode, whereas some tolerable fluctuations could be present due to the uniformity of the coating process.

\begin{tabular}{|c|c|c|c|c|c|}
\hline \multirow[b]{2}{*}{ Electrolyte } & \multicolumn{2}{|l|}{$25^{\circ} \mathrm{C}$} & \multicolumn{2}{|l|}{$-10^{\circ} \mathrm{C}$} & \multirow{2}{*}{$\begin{array}{l}\text { Capacity } \\
\text { retention } \\
\qquad(\%)\end{array}$} \\
\hline & $\begin{array}{c}\text { Discharge } \\
\text { capacity } \\
(\mathrm{mAh}) \\
\end{array}$ & $\begin{array}{l}\text { Discharge } \\
\text { time } \\
\text { (mins) }\end{array}$ & $\begin{array}{c}\text { Discharge } \\
\text { capacity } \\
(\mathrm{mAh})\end{array}$ & $\begin{array}{c}\text { Discharge } \\
\text { time } \\
\text { (mins) }\end{array}$ & \\
\hline Base & 2029.1 & 304.4 & 1590.4 & 239.0 & 78.32 \\
\hline Base+LFP & 2030.3 & 304.4 & 1588.9 & 239.9 & 78.26 \\
\hline Base+DTD & 2024.8 & 303.4 & 1597.7 & 241.1 & 78.91 \\
\hline Base+LiFSI & 2043.7 & 306.5 & 1618.1 & 241.7 & 79.18 \\
\hline Mix & 2033.2 & 305.0 & 1617.1 & 242.9 & 79.53 \\
\hline
\end{tabular}

Table S4. Discharge capacities and discharge times of the cells with different electrolytes under $-20^{\circ} \mathrm{C}$ and $25^{\circ} \mathrm{C}$ at $0.2 \mathrm{C}$, and the discharge capacity retentions. It should be mentioned that the capacity displayed herein corresponds to the total capacity of each cell (not the specific capacity), and depends on the thickness of the electrode, whereas some tolerable fluctuations could be present due to the uniformity of the coating process.

\begin{tabular}{|c|c|c|c|c|c|}
\hline \multirow[b]{2}{*}{ Electrolyte } & \multicolumn{2}{|l|}{$25^{\circ} \mathrm{C}$} & \multicolumn{2}{|l|}{$-20^{\circ} \mathrm{C}$} & \multirow{2}{*}{$\begin{array}{c}\text { Capacity } \\
\text { retention } \\
\quad(\%)\end{array}$} \\
\hline & $\begin{array}{c}\text { Discharge } \\
\text { capacity } \\
(\mathrm{mAh})\end{array}$ & $\begin{array}{c}\text { Discharge } \\
\text { time } \\
(\mathrm{mins}) \\
\end{array}$ & $\begin{array}{c}\text { Discharge } \\
\text { capacity } \\
(\mathrm{mAh})\end{array}$ & $\begin{array}{c}\text { Discharge } \\
\text { time } \\
\text { (mins) }\end{array}$ & \\
\hline Base & 2029.8 & 304.4 & 1321.7 & 200.2 & 65.11 \\
\hline Base+LFP & 2039.5 & 305.9 & 1309.6 & 197.8 & 64.21 \\
\hline Base+DTD & 2051.3 & 307.6 & 1344.4 & 201.8 & 65.54 \\
\hline Base+LiFSI & 2029.0 & 304.3 & 1345.9 & 202.3 & 66.33 \\
\hline Mix & 2021.9 & 303.1 & 1356.7 & 203.0 & 67.10 \\
\hline
\end{tabular}


Table S5. Cell thicknesses, ohmic resistances and discharge capacities before and after 10 days storage at $60^{\circ} \mathrm{C}$.

\begin{tabular}{lccccccc}
\hline & \multicolumn{7}{c}{ Before storage } \\
\cline { 2 - 7 } Electrolyte & $\begin{array}{c}\text { Cell } \\
\text { thickness } \\
(\mathrm{mm})\end{array}$ & $\begin{array}{c}\text { Ohmic } \\
\text { resistance } \\
(\mathrm{mOhm})\end{array}$ & $\begin{array}{c}\text { Discharge } \\
\text { capacity } \\
(\mathrm{mAh})\end{array}$ & $\begin{array}{c}\text { Cell } \\
\text { thickness } \\
(\mathrm{mm})\end{array}$ & $\begin{array}{c}\text { Ohmic } \\
\text { resistance } \\
(\mathrm{mOhm})\end{array}$ & $\begin{array}{c}\text { Retentive } \\
\text { discharge } \\
\text { capacity } \\
(\mathrm{mAh})\end{array}$ & $\begin{array}{c}\text { Recoverable } \\
\text { discharge } \\
\text { capacity } \\
(\mathrm{mAh})\end{array}$ \\
\cline { 2 - 8 } Base & 4.4 & 30.4 & 2020.5 & 4.61 & 39.4 & 1706.1 & 1980.3 \\
Base+LiFSI & 4.39 & 31.5 & 2035.9 & 4.53 & 37.3 & 1861.3 & 2008.7 \\
Base+LFP & 4.43 & 32.4 & 2013.5 & 4.62 & 41.4 & 1745.1 & 1979.7 \\
Base+DTD & 4.41 & 31.6 & 2014.1 & 4.57 & 38.1 & 1814.7 & 1989.0 \\
Mix & 4.39 & 30.3 & 2019.5 & 4.48 & 34.6 & 1906.4 & 2020.3 \\
\hline
\end{tabular}



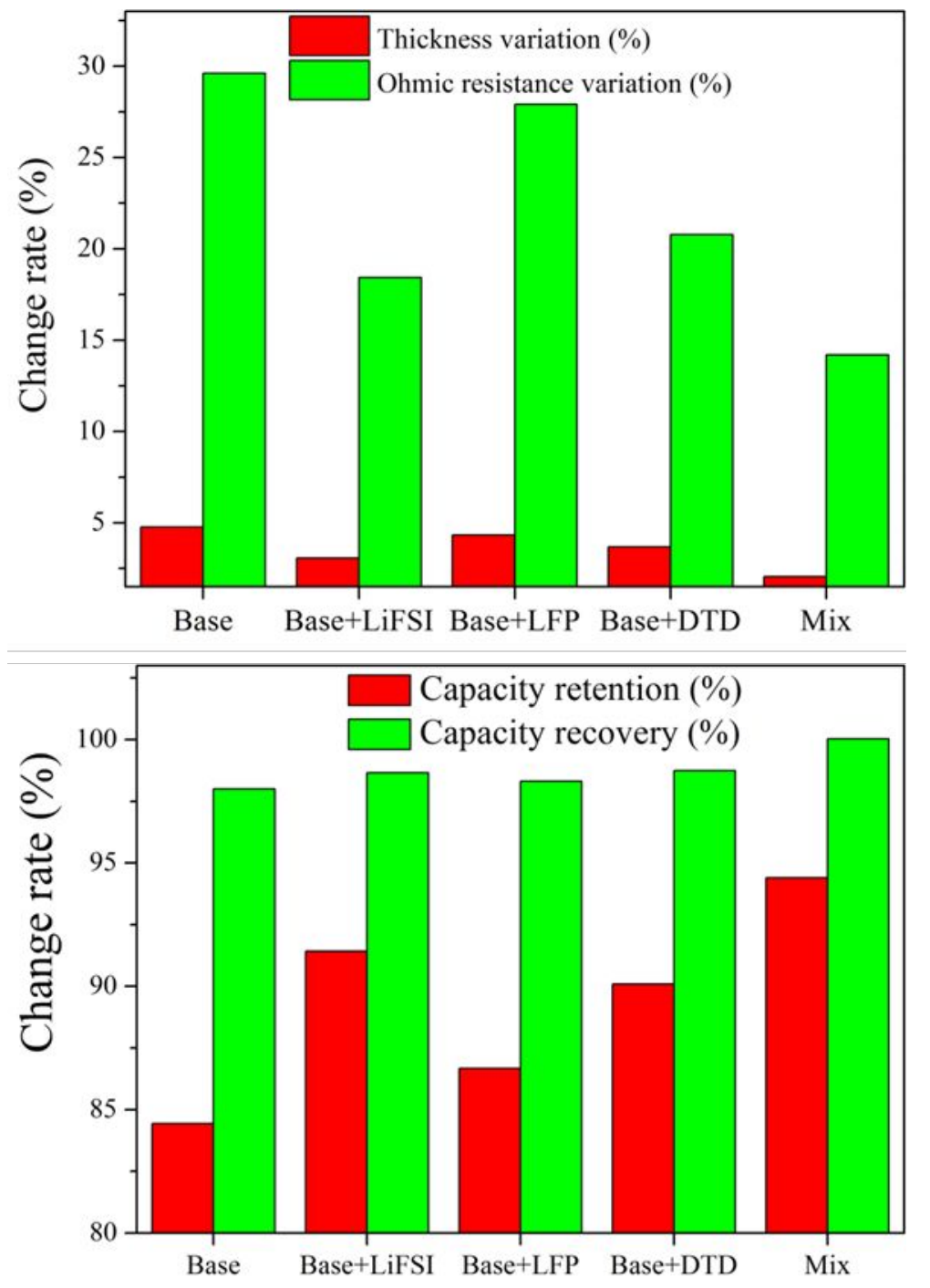

Figure S1. Thickness and ohmic resistance variations, capacity retentions and recoveries of the cells with different electrolytes before and after 10 days storage at 60 ${ }^{\circ} \mathrm{C}$. 
(a)
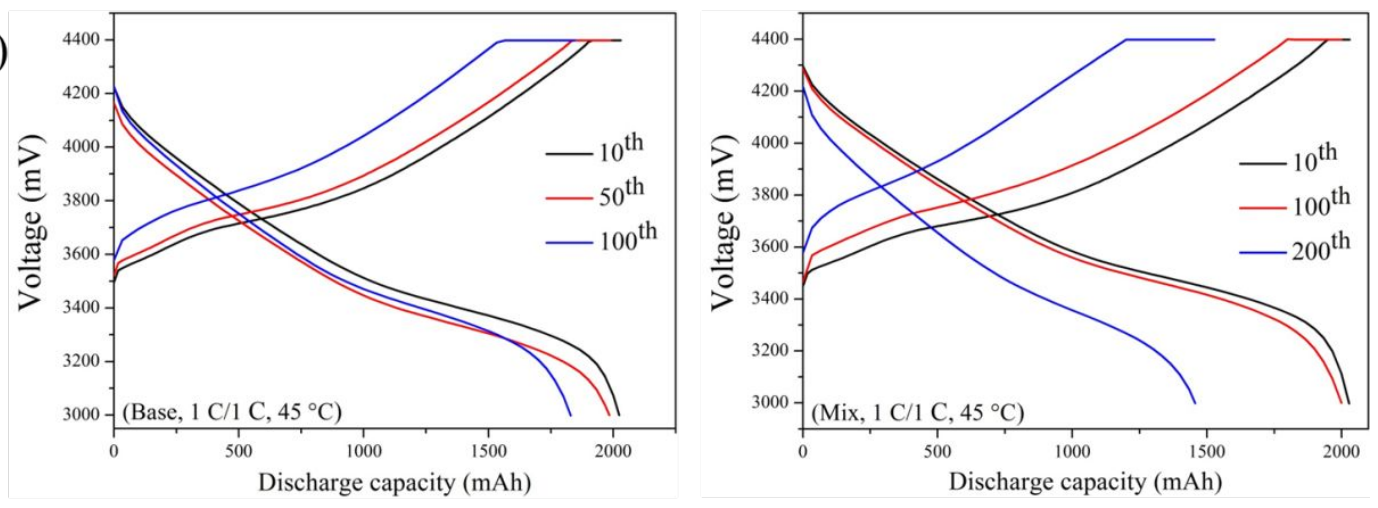

(b)
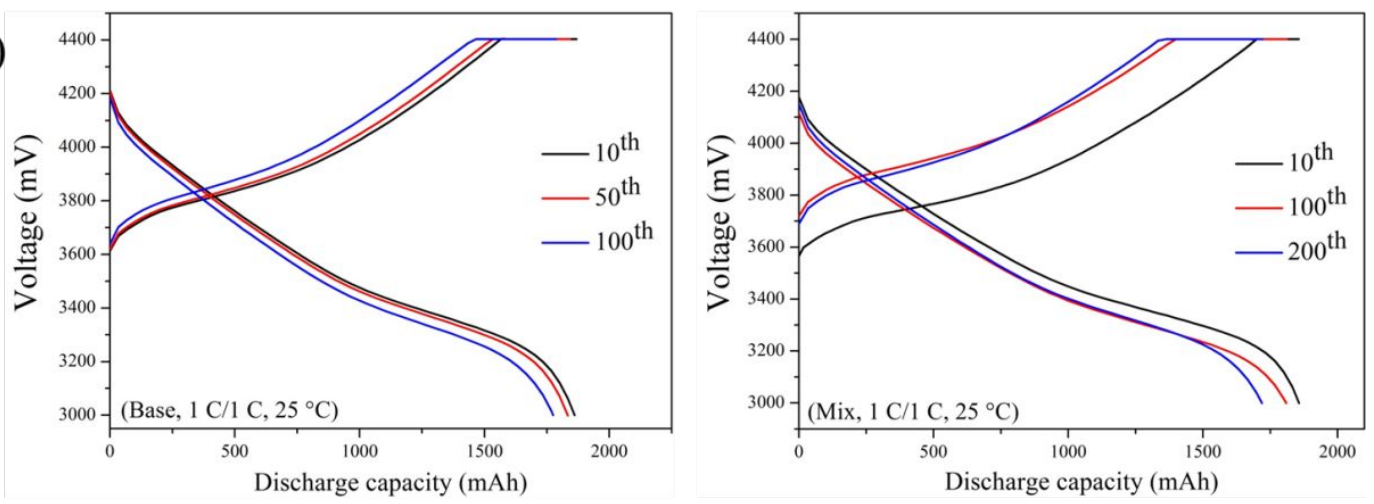

(c)
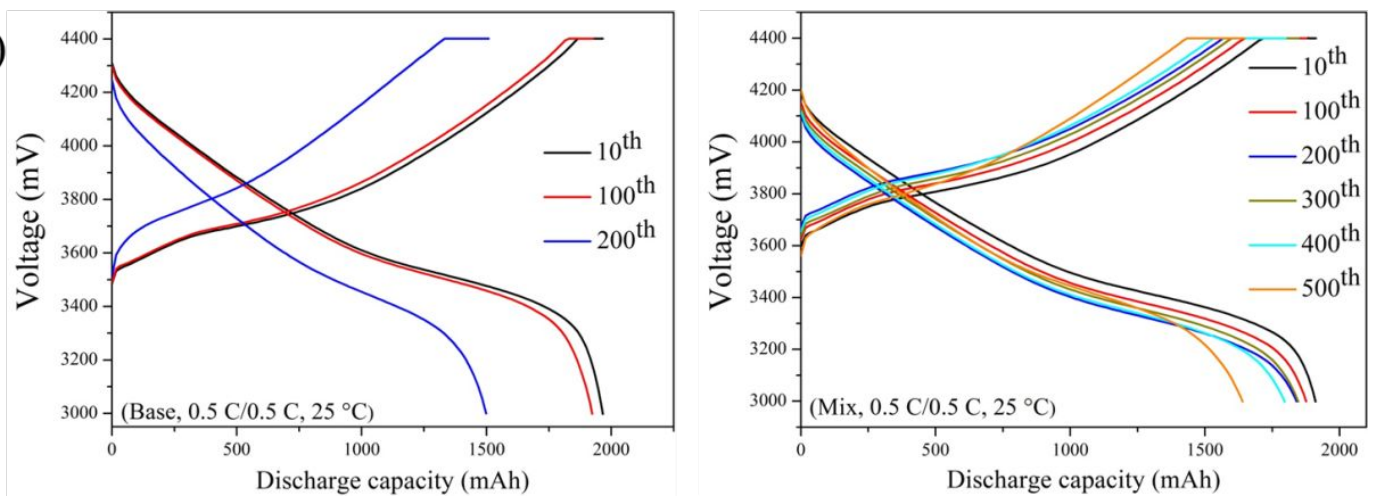

Figure S2. Charge-discharge curves of AGr/NCM523 pouch cells using the Base and Mix electrolytes upon cycling (a) at $1 \mathrm{C} / 1 \mathrm{C}$ under $45^{\circ} \mathrm{C}$, (b) at $1 \mathrm{C} / 1 \mathrm{C}$ under $25^{\circ} \mathrm{C}$, and (c) at $0.5 \mathrm{C} / 0.5 \mathrm{C}$ under $25^{\circ} \mathrm{C}$. 


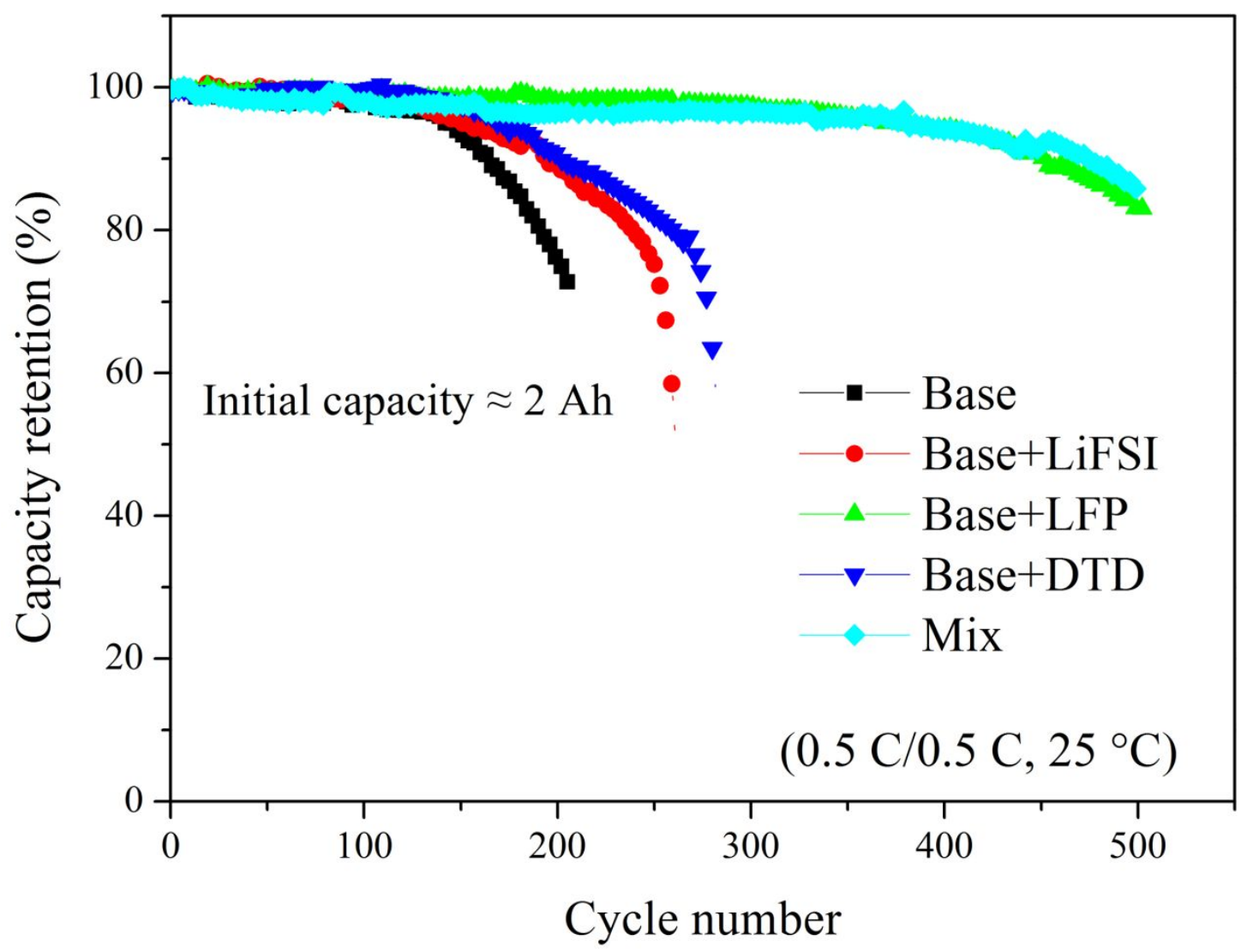

Figure S3. Cycling performances of AGr/NCM523 pouch cells at $0.5 \mathrm{C} / 0.5 \mathrm{C}$ under $25^{\circ} \mathrm{C}$. The performances of the cells using the Base electrolytes with/without single additive of LiFSI, LFP or DTD are compared. 

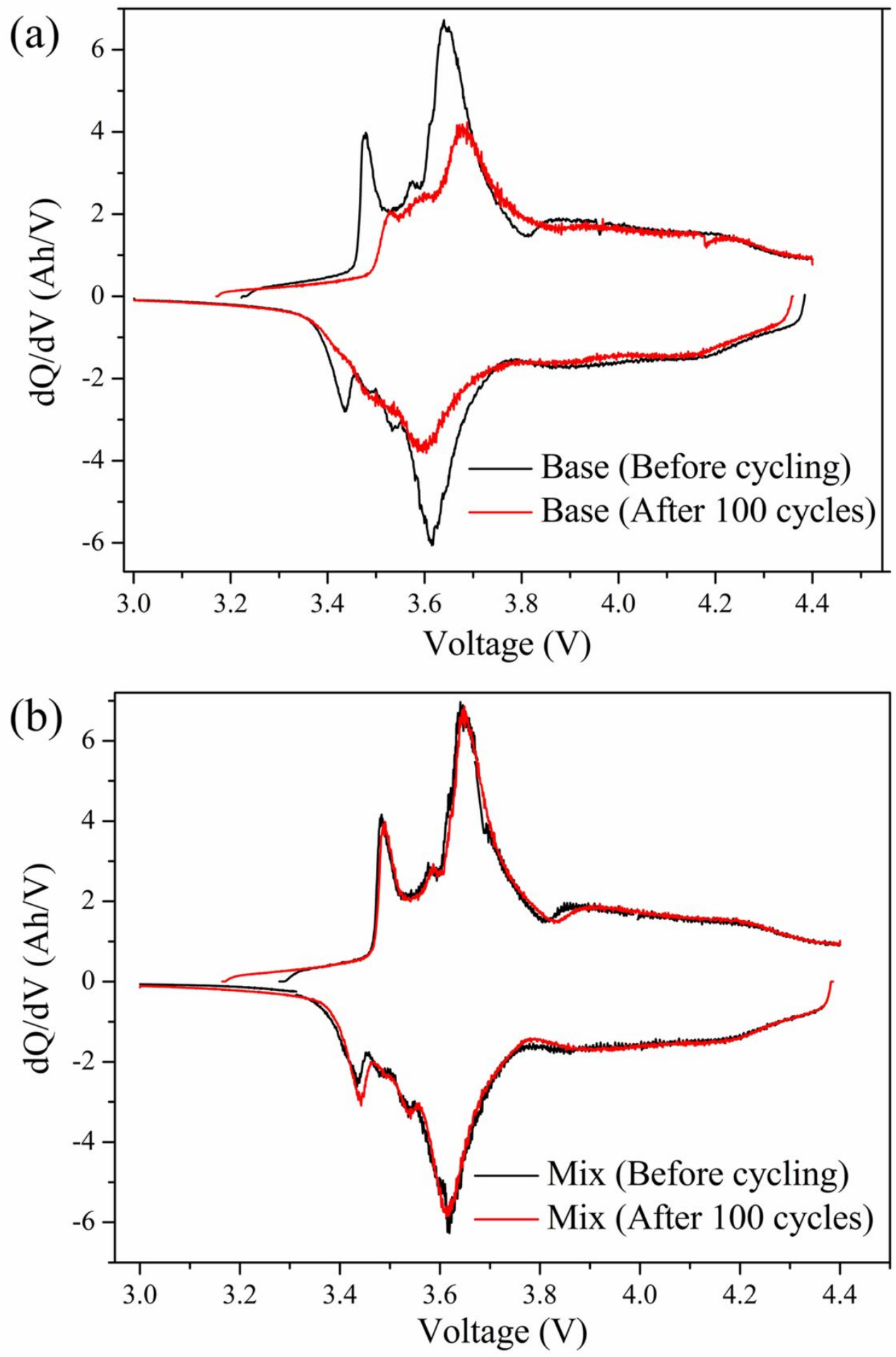

Figure S4. dQ/dV curves of the AGr/NCM523 cells using the (a) Base and (b) Mix electrolytes before and after 100 cycles at $0.5 \mathrm{C}$. 


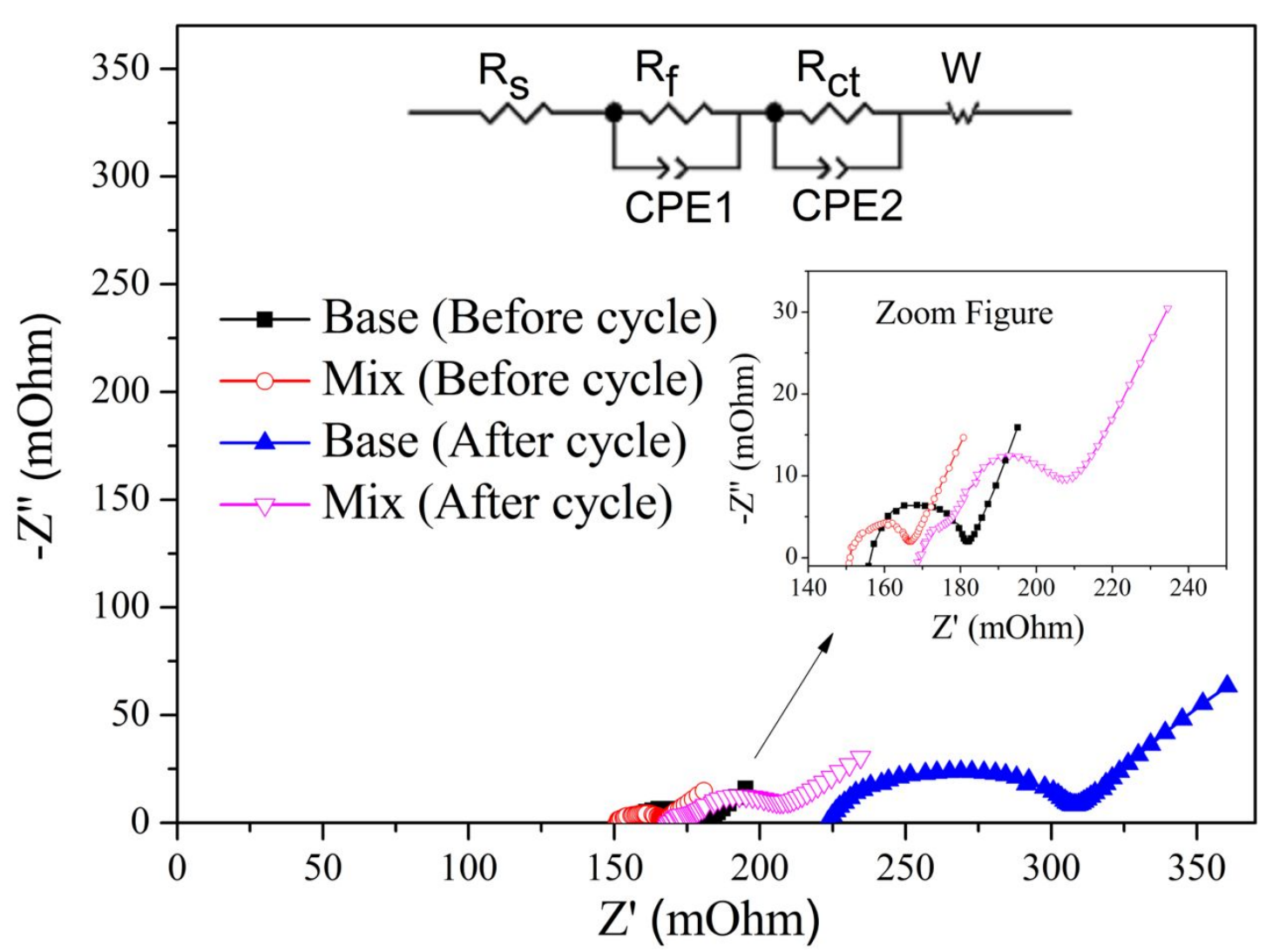

Figure S5. Nyquist plots of the AGr/NCM523 cells with different electrolytes before and after 100 cycles at $0.5 \mathrm{C}$. 


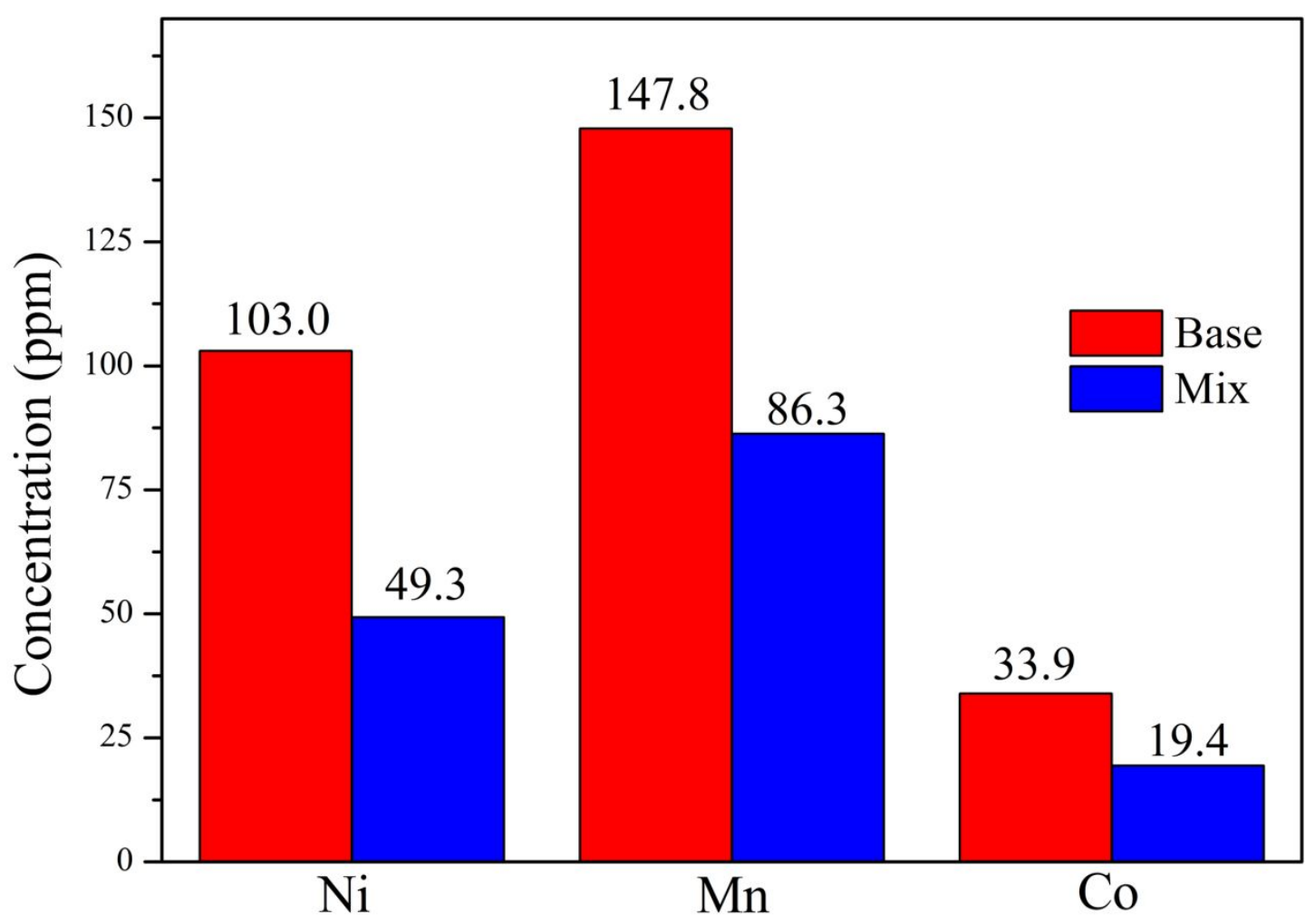

Figure S6. ICP-OES test of transition metal elements of the cycled AGr anodes in the Base and Mix electrolytes. 


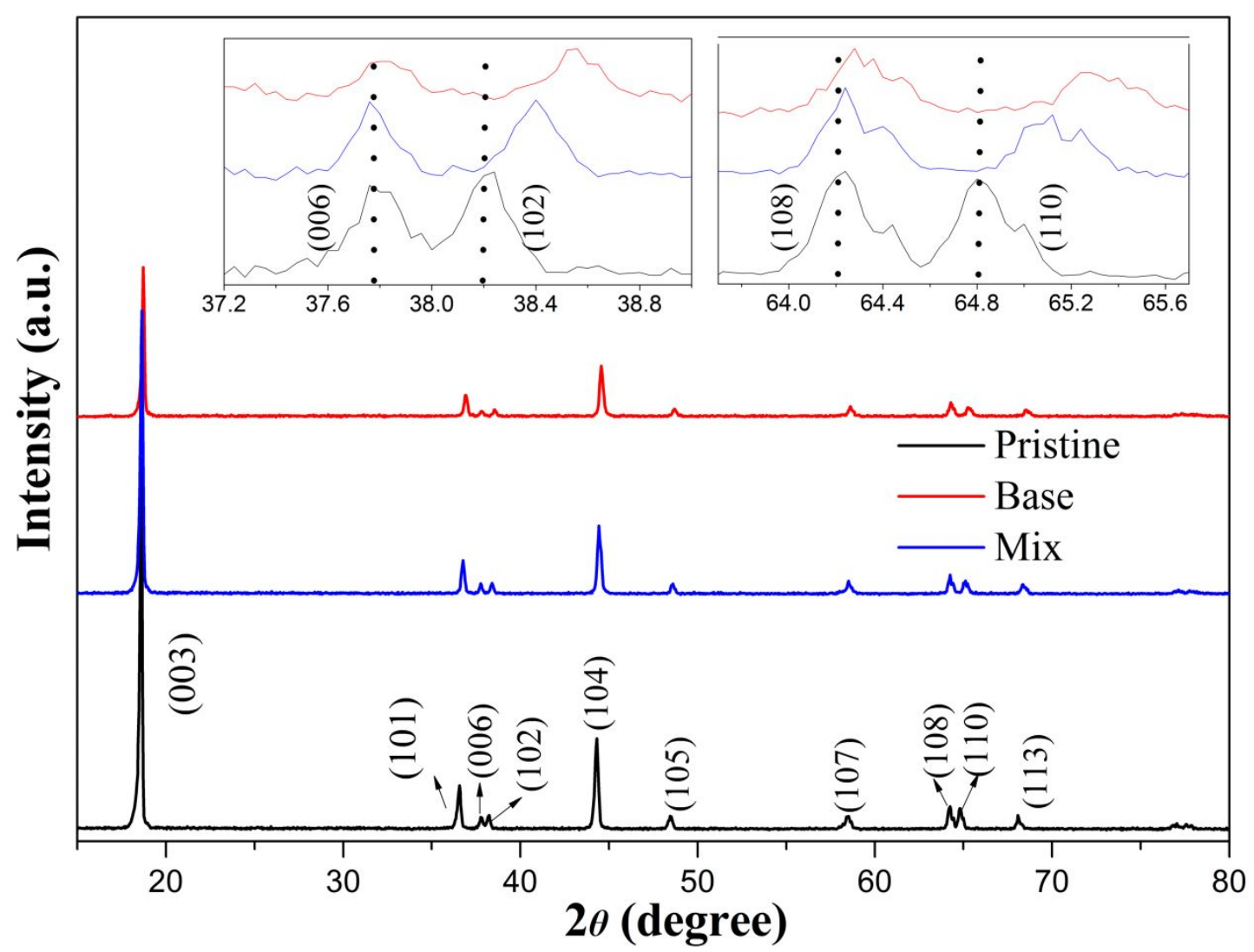

Figure S7. XRD patterns of the pristine and cycled NCM523 cathodes in the Base and Mix electrolytes. Inset of this graph is an expanded view of doublets of the $(006) /(102)$ peaks and $(108) /(110)$ peaks. 


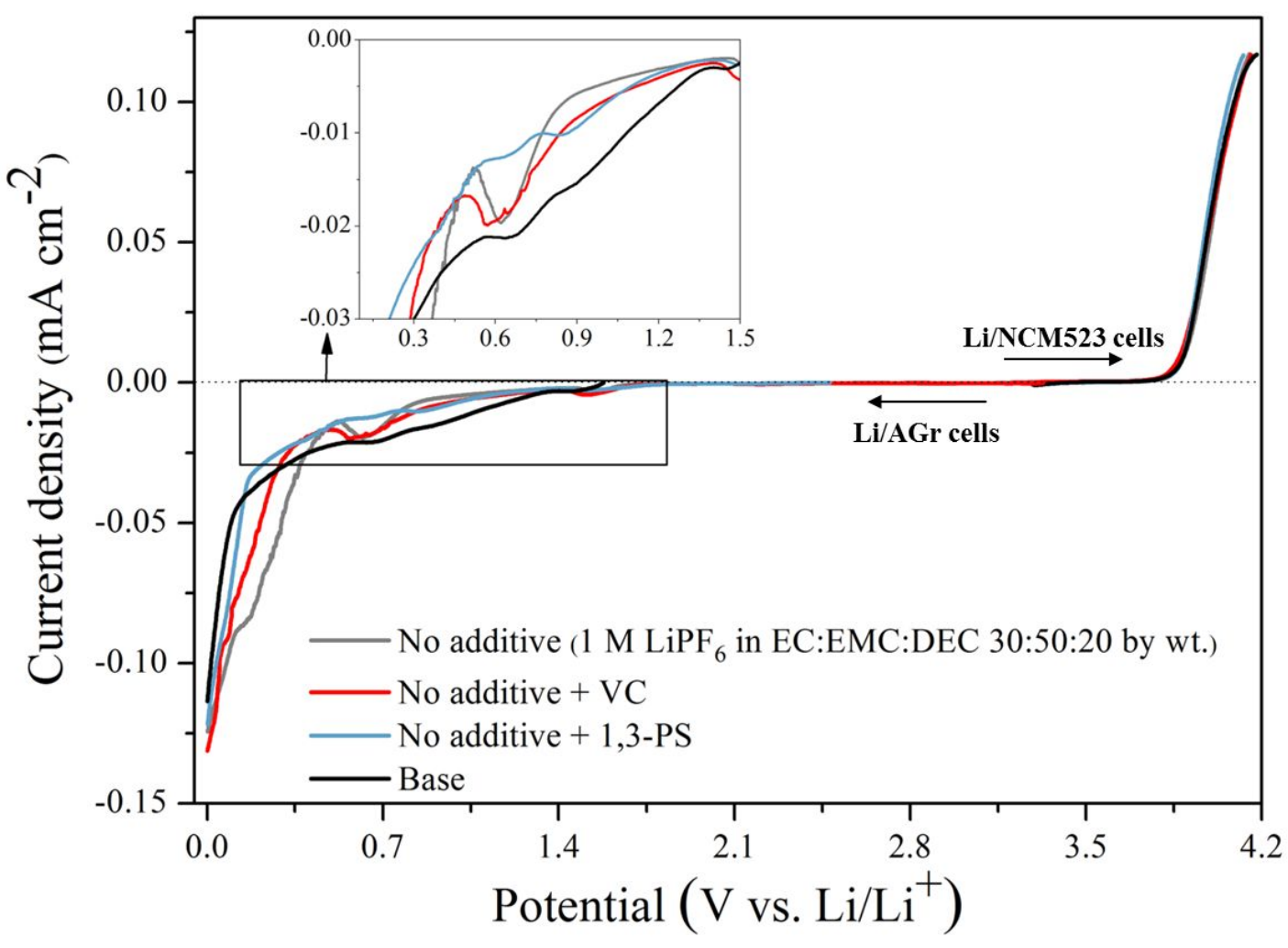

Figure S8. LSV curves of Li/NCM523 and Li/AGr half cells using the electrolyte without any additive, the electrolytes with single additive of VC or 1,3-PS, and the Base electrolyte, obtained at a scanning rate of $0.1 \mathrm{mV} \mathrm{s}^{-1}$. 

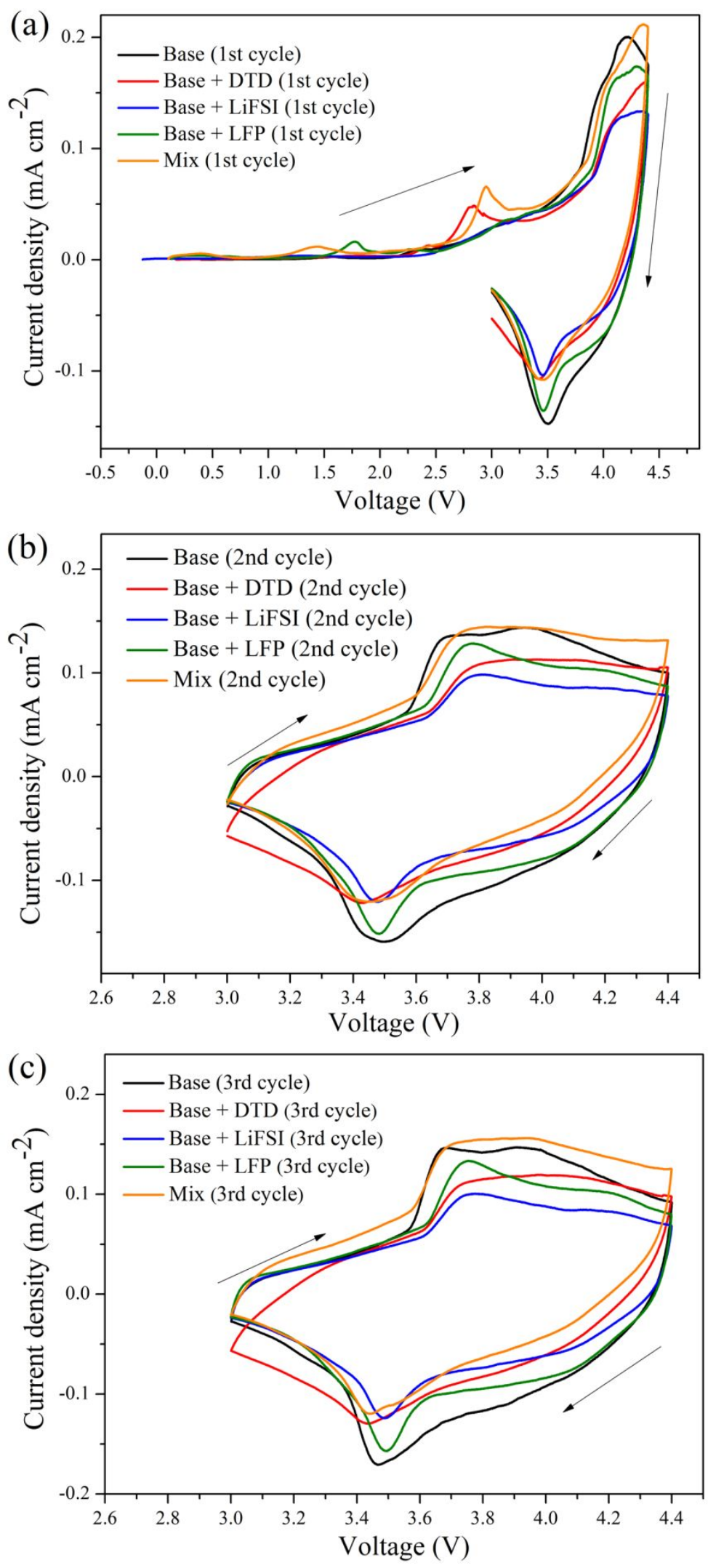

Figure S9. CV curves of the (a) $1^{\text {st }}$, (b) $2^{\text {nd }}$ and (c) $3^{\text {rd }}$ cycles of the Base electrolytes with/without the single use of DTD, LiFSI or LFP additives in the AGr/NCM523 coin cells. The CV scanning was performed at $0.1 \mathrm{mV} \mathrm{s}^{-1}$. 


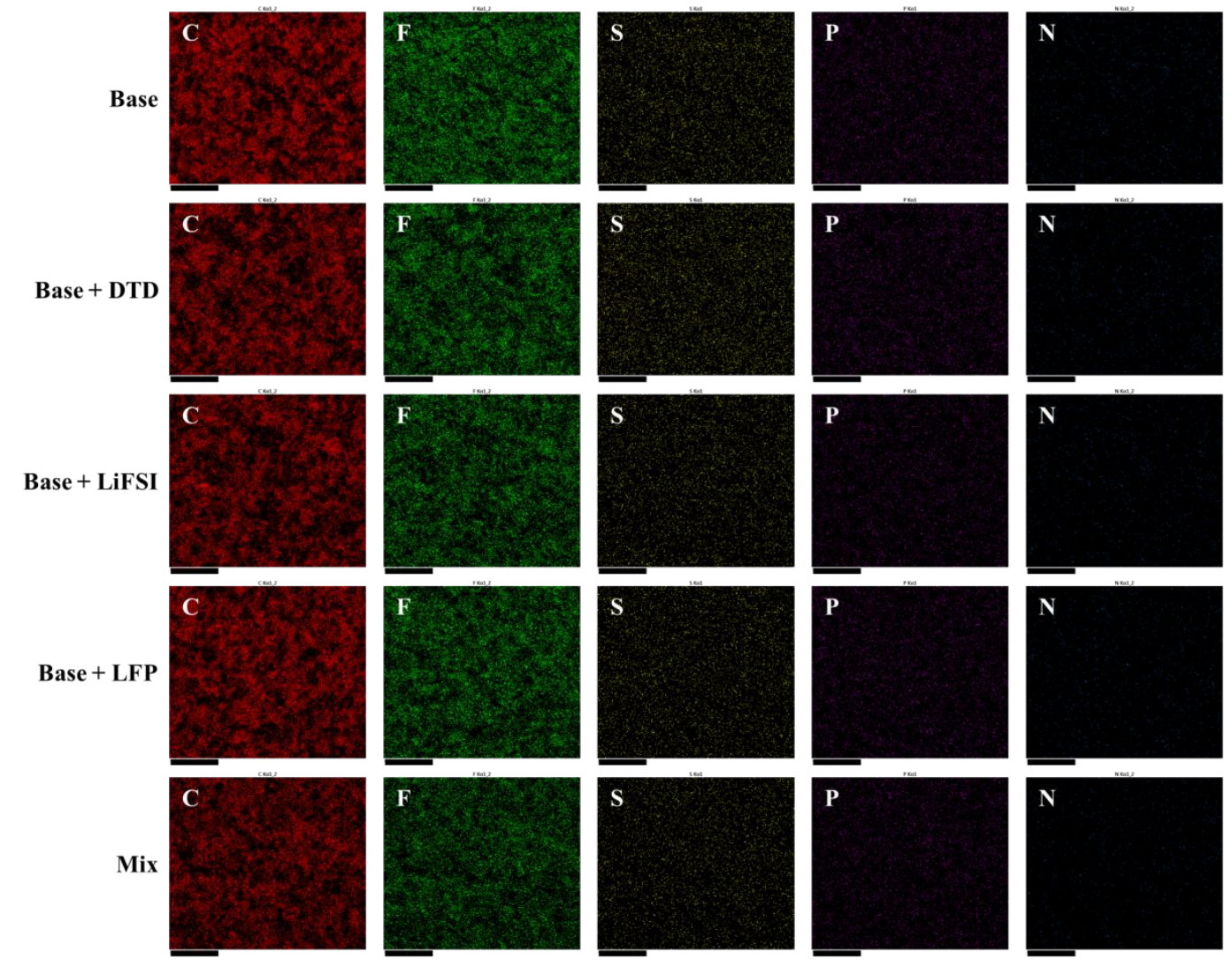

Figure S10. EDS mapping of the cycled NCM523 cathode surfaces after the LSV tests. 